\title{
MICROINCLUSIONS IN FIBROUS DIAMONDS FROM YUBILEINAYA KIMBERLITE PIPE (YAKUTIA)
}

\author{
Alla M. Logvinova ${ }^{1}$, Ofra Klein BenDavid ${ }^{2}$, Elad S.Izraeli ${ }^{2}$, Oded Navon ${ }^{2}$ and Nikolay V. Sobolev ${ }^{1}$ \\ ${ }^{I}$ Institute of Mineralogy and Petrography, SB RAS , Novosibirsk, Russia; ${ }^{2}$ Institute of Earth Sciences, The Hebrew \\ University, Jerusalem, Israel
}

\section{INTRODUCTION}

The Yubileinaya pipe is situated in the central part of the Daldyn-Alakit kimberlite field of the Yakutian diamondiferous province. The pipe age determined by the zircon-based U-Pb method is 358.1 Ma. (Davis et al., 1980). The new data on the inclusions of K-rich melts (Zedgenizov et al, 1998), Cr-Ca-rich majoritic garnet coexisting with a Cr-Ca-rich non-majoritic garnet and olivine (Sobolev et al, 2002), Fe-olivines (Sobolev et al, 2000) in Yubileinayan diamonds have been recently obtained. This fact was stimulus to investigate possible melt or fluid inclusions in Yubileinayan diamonds. Fluid or melt inclusions are valuable sources of direct information regarding the chemical composition of fluids in the upper mantle. It is known that fibrous diamonds contain numerous micro $(<1 \mu \mathrm{m})$ inclusions consisting of carbonates, water and incompatible elements. Such microinclusions are found in diamonds from Zaire, Botswana and South Africa (Navon et al, 1988; Akagi and Masuda, 1988, Schrauder and Navon, 1994, Izraeli et al., 2001). About $1 \%$ of the Yubileinayan diamonds have shapes which may be described as cubes (fibrous). Thus the present study focuses on the composition and origin of microinclusions in fibrous diamonds.

\section{METHODS}

Two fibrous cubes from Yubileynaya pipe (Ub-81 and Ub-541) have been studied. Double-polished sections $0.6-0.8 \mathrm{~mm}$ thick have been prepared from individual diamond crystals were studied using optical microscopes with transmitted and plane-pollarized light. Surface of this sections was cleaned with HF and HNO3. Shallow and subsurface inclusions were detected using backscattered electron-imaging and analysed for major-element composition using a JEOL JXA 8600 electron probe micro analyzer (EPMA) with Pioneer-Norvar EDS detector and automation system. Infrared spectra were recorded by the FTIR with Bruker IRscope II microscope coupled to a Nicolet 740 spectrometer for nitrogen concentration and aggregation-state and for the water and carbonate content of the microinclusions.

\section{RESULTS}

\section{Sample description}

All studied crystals have dark gray center and some dark zones (Fig.1). They are relatively flat-faced crystals of cubic habit, colorless. The surface of crystals carries dissolution forms. There are no cracks. Small cracks in the sample $\mathrm{Ub}-81$ are result of polishing. These diamonds fit variety II by Orlov. X-ray topography has shown fibrous internal structure of studied diamond.

There are many micro-inclusions inside the dark zones of studied crystals. The size of inclusions is about $1 \mu \mathrm{m}$.

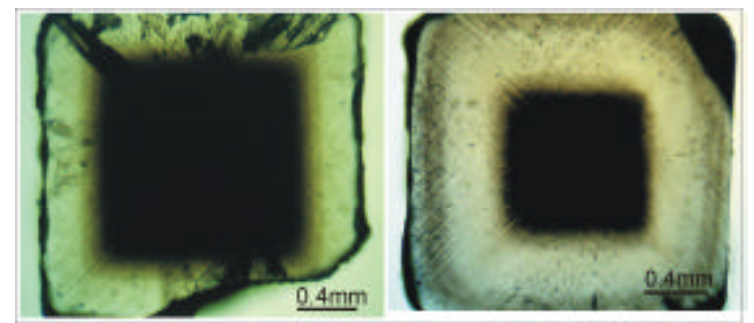

Figure 1: Polished sections of fibrous diamonds of cubic shape from Yubileinaya pipe (Ub-81 and Ub-541 resp.)

\section{Epma analyses}

EPMA detected two types of micro-inclusions: carbonatitic melt and sulfides. Diamond Ub-81 carry carbonatitic melt inclusions. The average composition of all the microinclusions is broadly similar. Their compositions vary the following ranges: $\mathrm{SiO}_{2}, 7-14$ wt. $\%$; $\mathrm{TiO}_{2}, 0$ - 5,5 wt.\%; $\mathrm{BaO}, 0$ - 6 wt. $\% ; \mathrm{Al}_{2} \mathrm{O}_{3}, 0$ - 3 wt.\%; FeO, 6 - 11 wt.\%; MgO, 20 - 30 wt.\%; CaO, 12 - 26 wt. $\%$; $\mathrm{Na}_{2} \mathrm{O}, 7$ - 11 wt. $\%$; $\mathrm{K} 2 \mathrm{O}, 16$ - 27 wt. $\%$; $\mathrm{P}_{2} \mathrm{O}_{5}, 2-8$ wt.\%; SrO, 0,6 - 4 wt.\%. All inclusions contain chlorine $(3-6 \%)$ (Fig. 2). On a triangular $\mathrm{Si}+\mathrm{Al}, \mathrm{K}+\mathrm{Na}, \mathrm{Mg}+\mathrm{Ca}+\mathrm{Fe}$ diagram the compositional points are closely situated. This fact confirms the presence of true melt inlusions in diamond.

The sample Ub-541 contains $\mathrm{S}-\mathrm{Ni}-\mathrm{Fe}$ rich inclusions. They are characterized the wide $\mathrm{S} / \mathrm{S}+\mathrm{Ni}+\mathrm{Fe}$ range and 
the high $\mathrm{Ni}$ content $(40 \pm 7$ wt. $\%)$. Similar high contents have been noted in the peridotitic MSS inclusions (about 15-36 wt.\%, Yefimova et al, 1983; Bulanova et al., 1995). Two carbonatitic melt inclusions similar to Ub-81 melt inclusion compositions are present in diamond Ub-541 along with sulfide
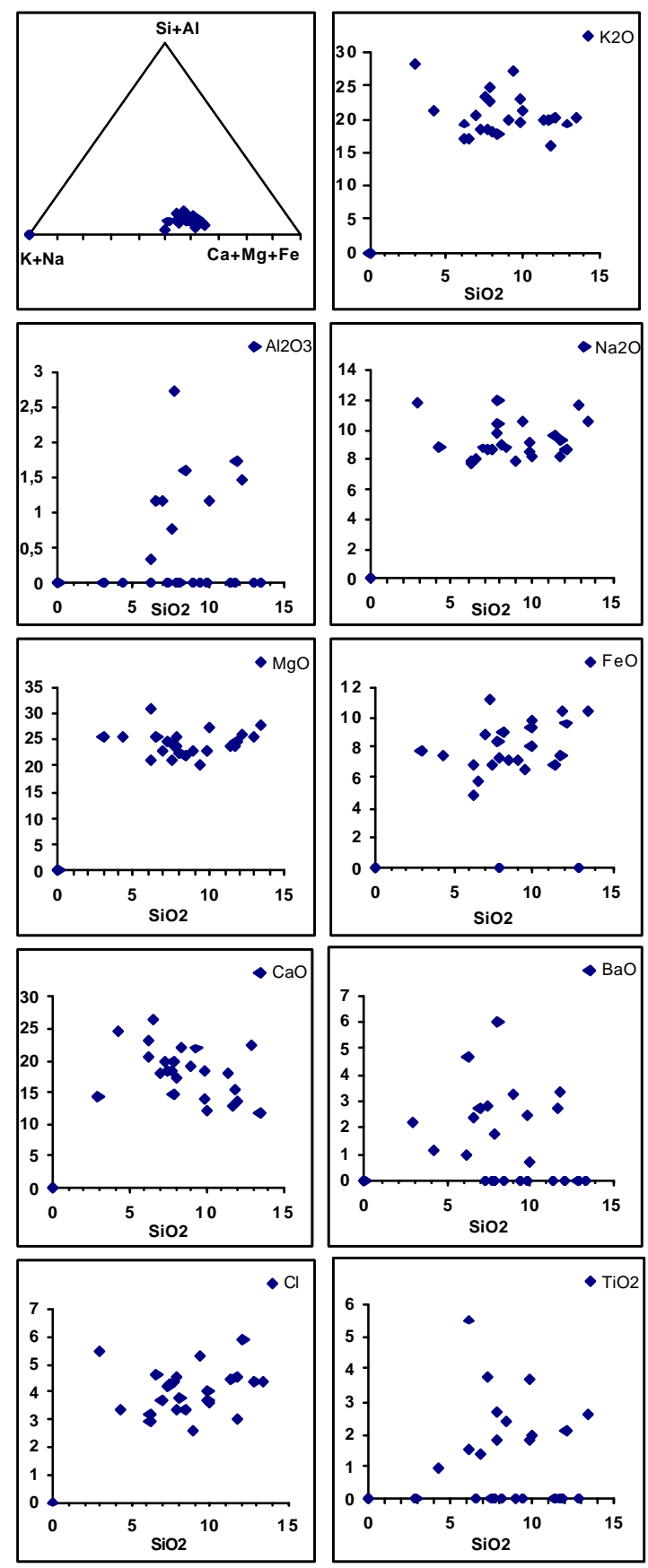

Figure 2: Concentrations of $\mathrm{K}_{2} \mathrm{O}, \mathrm{Na}_{2} \mathrm{O}, \mathrm{Al}_{2} \mathrm{O}_{3}, \mathrm{MgO}, \mathrm{FeO}$, $\mathrm{CaO}, \mathrm{BaO}, \mathrm{TiO}_{2}, \mathrm{Cl}$ vs. $\mathrm{SiO}_{2}$ of melt (or fluid) microinclusions in fibrous diamond Ub-81 from Yubileinaya pipe. inclusions. Some of these sulfide inclusions are composed of alkalis and $\mathrm{Mg}$.

\section{FTIR spectra}

FTIR spectroscopy indicates that the nitrogen aggregation state of cubic diamonds Ub-81 and Ub-541 is IaA-type. The measured nit rogen content is $1300-$ $1500 \mathrm{ppm}$.

The small bands at $1630 \mathrm{~cm}^{-1}$ and the more intense ones at $3420 \mathrm{~cm}^{-1}$ indicate the presence of water molecules in the diamond Ub-81 (Fig. 3). In the Ub-541 this bands are too small. Peaks at 3107 and $1405 \mathrm{~cm}-1$, being due to hydrogen in the diamond, detected in both samples. The intensities of the two characteristic carbonate bands at 1430 and $876 \mathrm{~cm}-1\left(\mathrm{CO}_{3}{ }^{2-}\right)$ are strongly correlated and their presence indicate on the existence of carbonate in the inclusions. In diamond Ub-81 this bands are strong (Fig. 3), in agreement with the detection of carbonatitic melt inclusions by EPMA. Similar carbonate-rich samples were reported in diamonds from Zaire and Botswana (Navon, 1988; Schrauder., 1994).
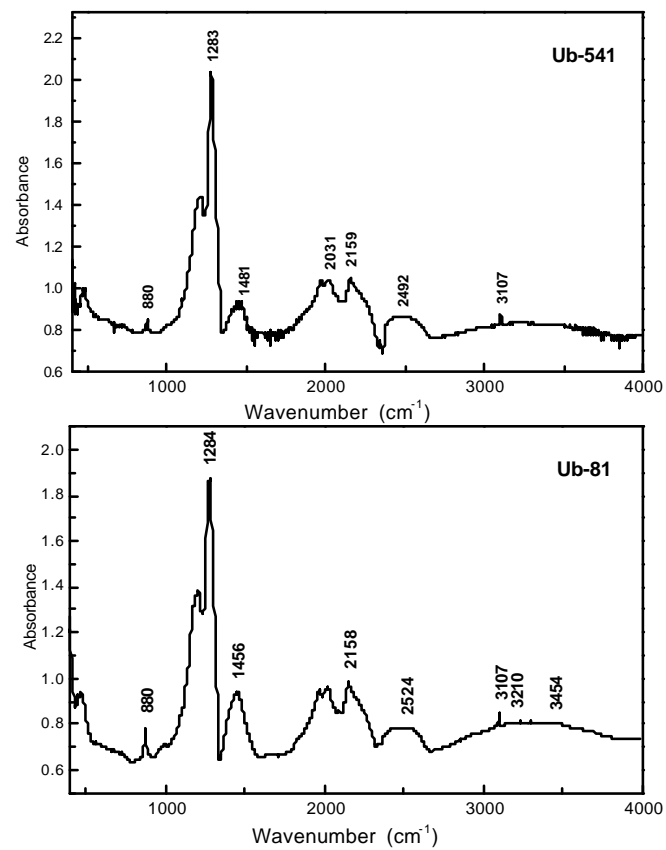

Figure 3: Infrared absorbance spectrum resulting from micro-inclusions in Yubileinayan diamonds $(400-4000$ $\mathrm{cm}^{-1}$ ) with strong carbonate bands at 880 and $1456 \mathrm{~cm}^{-1}$. Water bands at $3200-3450$ and $1640 \mathrm{~cm}-1$. Residual bands at $1284(1283)$ and $3107 \mathrm{~cm}^{-1}$ are due to nitrogen and hvdrogen in the diamonds 


\section{CONCLUSION}

The high content of volatiles and the uniform average composition of the micro-inclusions suggest that the original material trapped by diamond was a fluid-rich melt. Chlorine levels of $3-6 \mathrm{wt} \%$, reported here, are indeed much higher than those of kimberlites. The presence volatiles in the microinclusions along with enrichment in $\mathrm{K}, \mathrm{Na}, \mathrm{P}, \mathrm{Sr}$ suggests that the trapped material may represent an effective metasomatizing agent.

Broad compositional variations of S-Ni-Fe-inclusions, the constant $\mathrm{Ni} /(\mathrm{Ni}+\mathrm{Fe})$, the presence of varying amounts of alkalis and $\mathrm{Mg}$ and the association with carbonatitic melts suggest that the sulfide-bearing micro-inclusions do not contain a mineral phase. Thus established inclusions are regarded as sulfide melts.

The fibrous diamonds are considered to have formed rapidly, and also very low aggregation state of nitrogen observed by IR study also suggests that the diamonds have been brought to the earth surface in relatively short time after their production (Boyd et al., 1994). Thus the microinclusions trapped in the diamonds could be the substance occurred at the initial stage of diamond formation. Finding sulfide melts along with carbonatitic melts imply that those two compositions coexisted during the growth of diamond.

\section{REFERENCES}

Akagi, T., Masuda, A., 1988. Isotopic and elemental evidence for a relationship between kimberlite and Zaire cubic diamonds. Nature 334, 653-655.

Boyd, S.R., Pineaur, F. and Javoy, M., 1994. Modelling the growth of natural diamonds. Chem. Geol. 116, 29-42.

Bulanova, G.P., 1995. The fomation of diamond. J. Geochem. Explor. 53, 1-23.

Davis, G.L., Sobolev, N.V., Kharkiv, A.D., 1980. New data on the age of Yakutian kimberlites obtained by the U$\mathrm{Pb}$ method on zircons. Dokl. Akad. Nauk SSSR. 254, 175-179 (in Russian).

Izraeli, E.S., Harris, J.W., Navon, O., 2001. Brine inclusions in diamonds: a new upper mantle fluid. Earth Planet. Sci. Lett. 187, 323-332.

Navon, O., Hutcheon, I.D., Rossman, G.R., Wasserburg, G.L., 1988. Mantle-derived fluids in diamond microinclusions. Nature 335, 784-789.

Orlov, Yu.L., 1977. The Mineralogy of the Diamond. Wiley. New York.

Schrauder, M., Navon, O., 1994. Hydrous and carbonatitic mantle fluids in fibrous diamonds from Jwaneng, Botswana. Geochim. Cosmochim. Acta 58 (2), 761771.

Sobolev, N.V., Logvinova, A.M., Zedgenizov, D.A., Yefimova, E.S., Lavrent'ev, Yu.,G., 2000.
Anomalously high $\mathrm{Ni}$ admixture in olivine inclusions from microdiamonds, the Yubileinaya kimberlite pipe, Yakutia. Dokl. Akad. Nauk 375(3). 393-396 (in Russin). English Translation: Dokl. Earth Sci. 375A, 1403-1406.

Sobolev, N.V., Taylor, A.M., Logvinova, A.M., Seryotkin, Y.V., Koptil, V.I., Efimova, E.S., 2002. First report of majoritic-garnet diamond inclusions from Yakutian Kimberlites. AGU Fall Meeting, San Francisco, California, p. F1403.

Yefimova, E.S., Sobolev, N.V., Pospelova, L.N.,1983. Sulfide inclusions in diamonds and specific features of their paragenesis. Zapiski Vsesoyuznogo Mineralogicheskogo Obshchestva 112, 300-310 (in Russian).

Zedgenizov, D.A., Logvinova, A.M., Shatsky, V.S., Sobolev, N.V., 1998. Inclusions in microdiamonds from some kimberlite pipes (Yakutia). Dokl. Akad. Nauk 359(1), 74-78 (in Russian). English Translation: Dokl. Earth Sci. 359, 204-208.

Contact: AM Logvinova, Institute of Mineralogy and Petrography, 3 Koptyuga ave., Novosibirsk, 630090, RUSSIA, E-mail: logv@uiggm.nsc.ru 